\title{
Correlation of GM-CSF mRNA in bronchoalveolar fluid with indices of clinical activity in sarcoidosis
}

\author{
Akihide Itoh, Etsuro Yamaguchi, Ken Furuya, Nobuyuki Hizawa, Noritomo Ohnuma, \\ Yoshikazu Kawakami, Noboru Kuzumaki
}

\begin{abstract}
Background-Granulocyte-macrophage colony stimulating factor (GM-CSF) has several proinflammatory effects, some of which potentially favour granuloma formation. Its mRNA expression by the inflammatory cells recovered from lungs of patients with pulmonary sarcoidosis has been previously reported. In this study an association between GM-CSF expression and manifestations of the disease was explored.

Methods-GM-CSF mRNA was detected by reverse transcription polymerase chain reaction in the cells of bronchoalveolar lavage (BAL) fluid of 20 patients with pulmonary sarcoidosis.

Results-GM-CSF mRNA expression was positive in 15 of 20 patients with sarcoidosis. Fourteen of the 15 patients with positive mRNA expression had worsening or unchanged disease during the year preceding this study, on the basis of radiographic or physical findings, or both, whereas all five "negative" patients were judged to be improving. Similarly, serum levels of angiotensin converting enzyme, the proportion of lymphocytes in BAL fluid, and the CD4+/CD8 + ratio of lymphocytes in BAL fluid were significantly higher in the positive patients.

Conclusions-There was an association between the presence of GM-CSF mRNA in the cells in BAL fluid and other indices of disease activity in sarcoidosis.
\end{abstract}

First Department of Medicine

A Itoh

E Yamaguchi

K Furuya

N Hizawa

N Ohnuma

Y Kawakami

Laboratory of

Molecular Genetics,

Cancer Institute

N Kuzumaki

Hokkaido University

School of Medicine,

Kita-15 Nishi-7,

Kita-ku, Sapporo 060

Japan

Reprint requests to:

Dr E Yamaguchi

Received 13 November 1992

Returned to authors

3 March 1993

Revised version received

5 April 1993

Accepted 18 August 1993 favour granuloma formation.

In the search for cytokines that might be involved in sarcoid granuloma formation, we found that a sensitive reverse transcription polymerase chain reaction (RT-PCR) method often detected mRNA of granulocytemacrophage colony stimulating factor (GMCSF) in the cells in BAL fluid from patients with pulmonary sarcoidosis but not in the cells in BAL fluid from normal controls. ${ }^{4}$ Locally produced GM-CSF could promote granuloma formation via its effects on monocyte macrophage lineage cells.

To evaluate the relationship of GM-CSF with the disease process we compared patients with sarcoidosis whose BAL fluid cells expressed GM-CSF mRNA with those whose BAL fluid cells did not.

\section{Methods}

STUDY POPULATION

Twenty untreated Japanese patients with pulmonary sarcoidosis, including the six who had already been reported, ${ }^{4}$ were evaluated as to whether or not the cells in their BAL fluid expressed GM-CSF mRNA. The diagnosis of sarcoidosis was made according to previously described criteria including lung biopsy. ${ }^{5}$ Table 1 gives the demographic data of these 20 patients, all of whom were being followed at our sarcoidosis clinic. For comparison, five patients with extrinsic allergic alveolitis caused by Micropolyspora faeni, Thermoactinomyces vulgaris (farmer's lung), or both were studied in a similar fashion. The diagnosis of extrinsic allergic alveolitis was made by (1) exposure to causative antigens, (2) symptomatic acute episodes with cough and breathlessness 4-8 hours after exposure to specific antigens on the farm, (3) chest radiograph showing diffuse ground glass or micronodular shadowing with or without a restrictive pattern of pulmonary function, and (4) positive precipitating antibody to Micropolyspora faeni, Thermoactinomyces vulgaris, or both. In addition, transbronchial biopsy specimens were obtained in three patients. Granuloma formation was observed in two, and an interstitial mononuclear cell infiltrate compatible with chronic extrinsic allergic alveolitis was observed in the other one. They had all been separated from the causative antigen for a few weeks before BAL was performed.

\section{CLINICAL EVALUATION}

The patients were seen every three or six months depending on their disease status. 
Table 1 Characteristics of patients with sarcoidosis *

\begin{tabular}{|c|c|c|c|c|c|c|c|c|}
\hline No & Age & Sex & $\begin{array}{l}\text { Disease } \\
\text { duration } \\
\text { (years) }\end{array}$ & $\begin{array}{l}\text { Extrathoracic } \\
\text { disease }\end{array}$ & $\begin{array}{l}\text { Clinical } \\
\text { course }\end{array}$ & $\begin{array}{l}\text { Smoking } \\
\text { index } \\
\text { (pack years) } \dagger\end{array}$ & $\begin{array}{l}\text { Radiological } \\
\text { stage }\end{array}$ & $\begin{array}{l}\text { Serum angiotensin } \\
\text { converting enzyme } \\
(I U / l) \ddagger\end{array}$ \\
\hline 1 & 26 & $\mathbf{M}$ & 0 & + & Worse & $2 \cdot 25$ & 2 & $21 \cdot 6$ \\
\hline 2 & 20 & $\mathbf{F}$ & 3 & + & Unchanged & 0 & 1 & $25 \cdot 2$ \\
\hline 3 & 39 & $\mathbf{M}$ & 15 & - & Unchanged & $12 \cdot 5$ & 2 & $30 \cdot 2$ \\
\hline 4 & 42 & $\mathbf{F}$ & 11 & - & Unchanged & 0 & 1 & $20 \cdot 5$ \\
\hline 5 & 26 & $\mathbf{F}$ & 0 & + & Worse & $0 \cdot 3$ & 2 & $25 \cdot 8$ \\
\hline 6 & 29 & $\mathbf{M}$ & 2 & + & Unchanged & 0 & 2 & $27 \cdot 2$ \\
\hline 8 & 61 & $F$ & 1 & + & Unchanged & 0 & 2 & $5 \cdot 9$ \\
\hline 9 & 52 & $\mathbf{F}$ & 6 & + & Unchanged & 0 & 1 & $34 \cdot 7$ \\
\hline 10 & 55 & F & 6 & + & Better & 0 & 1 & $27 \cdot 8$ \\
\hline 11 & 26 & $\mathbf{F}$ & 0 & + & Worse & 0.65 & 1 & $11 \cdot 3$ \\
\hline 12 & 30 & $\mathbf{F}$ & 3 & - & Worse & 0 & 2 & $20 \cdot 4$ \\
\hline 13 & 53 & $M$ & 1 & + & Unchanged & 60 & 1 & $21 \cdot 2$ \\
\hline 14 & 22 & $\mathrm{~F}$ & 1 & + & Unchanged & $1 \cdot 5$ & 1 & $11 \cdot 0$ \\
\hline 15 & 64 & $\mathrm{~F}$ & 10 & - & Unchanged & 0 & 0 & $13 \cdot 7$ \\
\hline 16 & 33 & $M$ & 2 & - & Better & $12 \cdot 75$ & 0 & 9.9 \\
\hline 18 & 53 & $M$ & 6 & - & Better & 0 & 1 & $12 \cdot 0$ \\
\hline 19 & 54 & $\mathrm{~F}$ & 3 & - & Better & $37 \cdot 5$ & 0 & $15 \cdot 7$ \\
\hline 20 & 25 & $\mathbf{M}$ & 1 & - & Better & 5 & 0 & $7 \cdot 0$ \\
\hline
\end{tabular}

^Patients $1,2,3,4,15$, and 16 were previously reported. ${ }^{4}$

†Patients $3,7,11,13$, and 16 were ex-smokers at the time of the study.

$\ddagger$ Normal value $=8-21 \mathrm{IU} / 1$.

Chest radiography and pulmonary function tests (spirometry and diffusing capacity by carbon monoxide single breath method) were performed annually, followed by BAL within two weeks. Disease duration, presence or absence of extrathoracic disease, smoking status, and serum angiotensin converting enzyme levels were collected from the case notes (table 1).

The clinical course was classified as worse, unchanged, or better by comparing physical findings, chest radiographs, and the results of pulmonary function tests just before BAL and a year earlier. These three criteria were not contradictory in any subject. Radiological changes were evaluated by two independent respiratory physicians without knowledge of other findings. In the pulmonary function tests a $10 \%$ or greater change from the previous value was considered significant.

BAL

After informed consent was given by the subject, BAL was performed as previously described. ${ }^{6}$ Briefly, three to four $50 \mathrm{ml}$ aliquots of sterile saline were infused into a lingular segment and then recovered by gentle suction immediately after each infusion. Cells were collected by centrifugation and washed once with cold Hanks' balanced salt solution (HBSS, GIBCO, Grand Island, USA).

\section{DETECTION OF GM-CSF MRNA}

RNA was immediately extracted from the cells in the BAL fluid by the guanidium isothiocyanate caesium chloride method, except in patient 3 whose alveolar macrophages were enriched. ${ }^{4}$ RT-PCR followed by Southern blot analysis was used to detect GM-CSF mRNA as previously described. ${ }^{4}$ Briefly, $1 \mu \mathrm{g}$ of total RNA obtained from BAL fluid cells was reverse transcribed and the resulting cDNA was then amplified by 30 cycles of polymerase chain reaction. The sequences of the primer oligonucleotides are given below. This set of oligonucleotides spans a $268 \mathrm{bp}$ region (nucleotides 144-411) of GM-CSF cDNA ${ }^{7}$ : (5' (sense) primer, 5'-AGTAGAGACACTGCTGCTGA-3'; 3' (anti-sense) primer, 5'-GGATGACAAGCAGAAAGTCC-3').

After PCR, $1 / 20$ of the reaction mixture was analysed by Southern blotting. Peripheral blood mononuclear cells stimulated with $0.1 \%$ phytohaemagglutinin (PHA-P, Difco, Detroit, USA) and $5 \mathrm{ng} / \mathrm{ml}$ phorbol myristate acetate (Sigma, St. Louis, USA) for 24 hours in RPMI1640 (GIBCO) with $10 \%$ fetal calf serum (GIBCO) were used as a positive control. GM-CSF cDNA probe was a purified fragment of the pHTB194b plasmid, which was a generous gift of Genetics Institute Inc. (Cambridge, USA).

\section{STATISTICS}

Representative values were given as mean (SE) and comparisons between groups were made with the Student's two tailed $t$ test unless otherwise indicated. A p value $<0.05$ was considered significant.

\section{Results}

The results of BAL are shown in table 2. In all subjects more than $90 \%$ of the lymphocytes recovered by BAL were found to be CD3 + $\mathrm{T}$ lymphocytes by flow cytometric

Table 2 Mean (SE) results of bronchoalveolar lavage

\begin{tabular}{lcc}
\hline & $\begin{array}{l}\text { Sarcoidosis } \\
(n=20)\end{array}$ & $\begin{array}{l}\text { Extrinsic allergic } \\
\text { alveolitis } \\
(n=5)\end{array}$ \\
\hline Total cell no. $\left(\times 10^{-6}\right)$ & $21 \cdot 2(3 \cdot 0)$ & $31 \cdot 4(8 \cdot 1)$ \\
Differential cell counts (\%) & $63 \cdot 9(5 \cdot 9)$ & $33 \cdot 0(2 \cdot 4)$ \\
Macrophages & $35 \cdot 3(5 \cdot 9)$ & $64 \cdot 8(2 \cdot 6)$ \\
Lymphocytes & $0 \cdot 5(0 \cdot 2)$ & $1 \cdot 8(1 \cdot 2)$ \\
Neutrophils & $0 \cdot 3(0 \cdot 1)$ & $0 \cdot 1(0 \cdot 1)$ \\
Eosinophils & & \\
Lymphocyte subsets & $68 \cdot 1(3 \cdot 5)$ & $86 \cdot 2(2 \cdot 1)$ \\
CD4+ (\%) & $24 \cdot 8(3 \cdot 8)$ & $10 \cdot 7(1 \cdot 6)$ \\
CD8+ (\%) & $4 \cdot 0(0 \cdot 6)$ & $9 \cdot 8(2 \cdot 9)$ \\
CD4 + /CD8 + ratio & & \\
\hline
\end{tabular}

^Lymphocyte subsets were not determined in patients 4 and 15. 
Figure 1 Detection of GM-CSF $m R N A$ by a combination of reverse transcription polymerase chain reaction (RT-PCR) and Southern blotting. Hybridisation bands of 268 bp on lanes 1-15 demonstrate GM-CSF mRNA expression. Lanes 1-20 represent patients 1-20 with sarcoidosis shown in table 1; lanes 21-25 represent patients with extrinsic allergic alveolitis; lane P: 10 times dilution of the RT-PCR product of RNA from peripheral blood mononuclear cells stimulated with $0 \cdot 1 \%$ phytohaemagglutinin and $5 \mathrm{ng} / \mathrm{ml}$ phorbol myristate acetate for 24 hours.

Figure 2 Comparison of serum levels of angiotensin converting enzyme between sarcoidosis patients with positive $(+)$ and negative (-) GM-CSF $m R N A$ expression by $B A L$ cells. Bars indicate mean (SE). analysis (data not shown). Patients with sarcoidosis and extrinsic allergic alveolitis had increased percentages of lymphocytes, and an increased $\mathrm{CD} 4+/ \mathrm{CD} 8+$ ratio which indicated that helper $\mathrm{T}$ cells were dominant. The increase in CD4 $+\mathrm{T}$ cells was higher in the patients with extrinsic allergic alveolitis. For some unknown reason $\mathrm{CD} 4+$ dominance in cells of BAL fluid is a common finding in Japanese patients with farmer's lung, ${ }^{8}$ whereas it is less frequently observed in other regions. ${ }^{9}$

The RNA samples obtained from patients 1-15 in table 1 contained GM-CSF mRNA as shown by the 268 bp hybridisation bands (fig 1). These bands were faint compared with the positive control (lane $P$ in fig 1,10 times dilution of the RT-PCR product of RNA from peripheral blood mononuclear cells stimulated with phytohaemagglutinin and phorbol myristate acetate), showing the low copy number of GM-CSF mRNA in BAL fluid cells. No patient with extrinsic allergic alveolitis gave a positive band.

Five patients were judged as having "worse" disease than one year previously. Three (nos. 1, 5, and 11) had newly diagnosed sarcoidosis and were judged as such

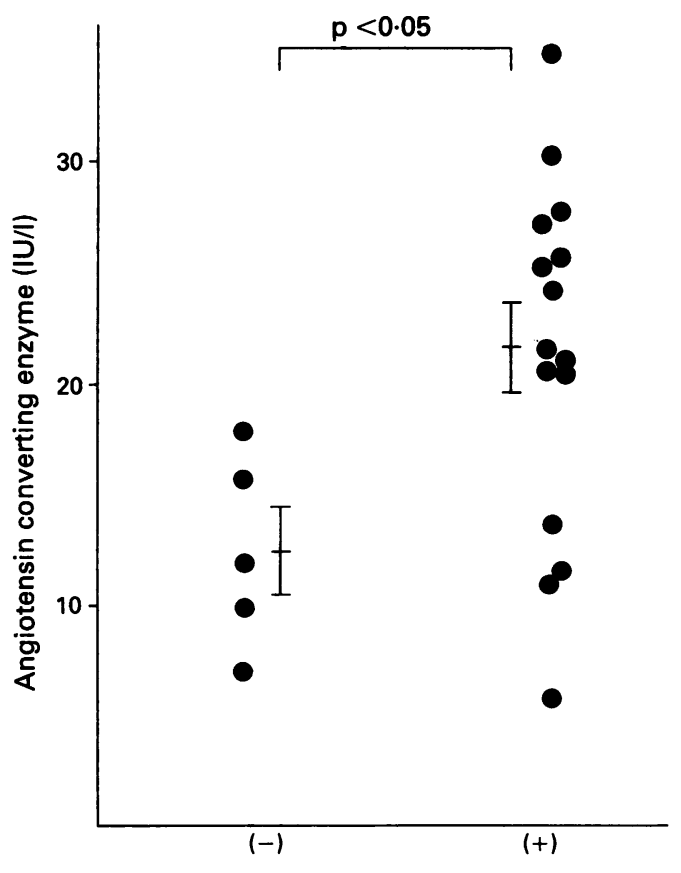

GM-CSF mRNA because they unequivocally noted the onset of extrathoracic symptoms (visual disturbance in all, Heerfordt's syndrome in patient 5 , and superficial node swelling in patient 11). Earlier normal chest radiographs were also available in patients 1 and 5 . Of the other two, patient 7 developed skin granuloma and a $10 \%$ decrease of diffusing capacity, and patient 12 developed diffuse pulmonary infiltrates on the chest radiograph. In all six patients in whom the disease was judged to be "better", shrinkage of bilateral hilar lymphadenopathy was observed without development of parenchymal shadows or deterioration in pulmonary function.

Clinical features of the patients who gave positive GM-CSF mRNA expression by the cells in their BAL fluid (patients 1-15, positive group) were compared with those of the patients who did not (patients 16-20, negative group). All patients in the negative group were judged as being clinically better than one year previously, whereas 14 of the 15 patients in the positive group had no improvement ( $p<0.001$, Fisher's exact probability test). These two groups were not statistically different in disease duration and smoking index.

The laboratory findings of the positive and negative groups were compared. Serum levels of angiotensin converting enzyme were higher in the positive group $(21.4(2.1) v 12.5(2.0)$ IU/1, p < 0.05) (fig 2). The percentage of lymphocytes and $\mathrm{CD} 4+/ \mathrm{CD} 8+$ ratio of lymphocytes in BAL fluid were higher in the positive group $(44 \cdot 3(6 \cdot 2) \% v 8 \cdot 2(2 \cdot 7) \%$, and $5.0(0.6) v 1.5(0.4)$, respectively, $\mathrm{p}<0.01$ for both) (fig 3).

\section{Discussion}

Pulmonary sarcoidosis is characterised by an intense cellular immune response localised within the lung. The inflammatory cells recovered from the sarcoid lung by BAL spontaneously release cytokines including IL1 , IL-2, and interferon $\gamma,{ }^{1-3}$ which are considered to mediate the inflammatory reaction. In this report we have investigated the possible involvement of GM-CSF as another inflam matory mediator.

Because GM-CSF is usually produced in very small quantities and its mRNA cannot be detected in cells in BAL fluid by conven- 
Figure 3 Comparisons of findings in cells in bronchoalveolar lavage (BAL) fluid between sarcoidosis patients with positive (+) and negative (-) GM-SCF $m R N A$ expression by $B A L$ cells. Bars indicate mean (SE). Analysis of lymphocyte
subsets was not done in patients 4 and 15.
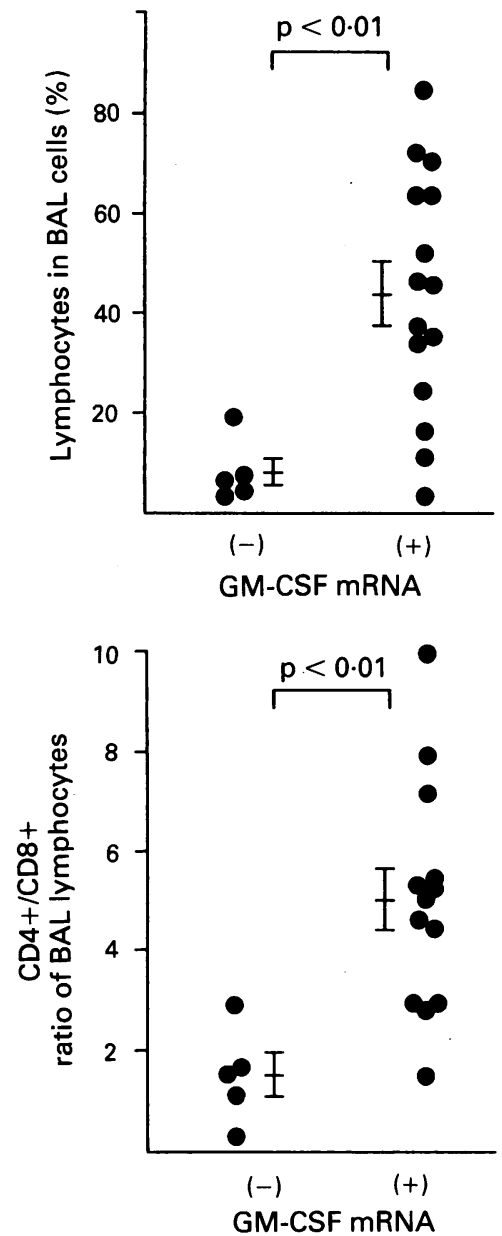

tional methods, ${ }^{7011}$ we used a sensitive RTPCR method to detect GM-CSF mRNA in BAL fluid cells. In contrast to the absence of detectable GM-CSF mRNA in normal controls even by this method, ${ }^{4}$ GM-CSF mRNA was detected in 15 of the 20 patients with pulmonary sarcoidosis including those six who had previously been reported. ${ }^{4}$ Five with pulmonary sarcoidosis failed to express GMCSF mRNA, all of whom had improving disease, while most of the patients with GM-CSF mRNA expression had unchanged or worsening disease. Patients with GM-CSF expression also had higher values of such "activity" markers as serum levels of angiotensin converting enzyme, percentage of lymphocytes in BAL fluid cells, and CD4 +/ CD8 + ratio of lymphocytes in BAL fluid. ${ }^{12-14}$ These results indicated that GM-CSF expression roughly paralleled the clinical spectrum of the disease. Since serum levels of angiotensin converting enzyme may reflect the extent and activity of granulomas in the body, and the cells in BAL fluid represent the inflammation in the alveolar structures, our findings suggest that GM-CSF released from the inflammatory cells within the lung promotes granuloma formation and, ultimately, leads to worse disease. However, a prospective study enrolling more patients controlled for such clinical parameters as smoking habit and radiographic stage would be needed to clarify the role of GM-CSF in disease manifestation or prognosis.
One might argue that the small amount of GM-CSF mRNA simply reflected the BAL T lymphocytosis, as the $\mathrm{T}$ cell is one of the major sources of GM-CSF. ${ }^{70}$ We feel this possibility unlikely from the following observations. Firstly, GM-CSF expression was seen in patients with a normal percentage of lymphocytes in the BAL fluid. Secondly, we failed to detect GM-CSF mRNA in several samples of unstimulated peripheral blood mononuclear cells which are usually rich in $\mathrm{T}$ cells (data not shown). Thirdly, BAL fluid cells of the patients with extrinsic allergic alveolitis did not contain GM-CSF mRNA though the percentage of lymphocytes in the BAL fluid and CD4 +/CD8 + ratio of lymphocytes in BAL fluid were higher in these patients than in the sarcoidosis patients with GM-CSF mRNA expression $(64 \cdot 8(2 \cdot 6) \% v$ $44.3(6.2) \%, 0.05<\mathrm{p} 0 \cdot 1$, and $9 \cdot 8(2 \cdot 9) \quad v$ $5 \cdot 0(0 \cdot 6), \mathrm{p}<0.05$, respectively). GM-CSF mRNA expression by the cells in BAL fluid may therefore be a manifestation of their functional activation in sarcoidosis.

We did not separate the cells in the BAL fluid into $T$ lymphocytes and alveolar macrophages because the mRNA expression of the cells in the BAL fluid. might have been altered by the time required or by exogenous agents such as antibodies and plastic surface. Consequently, the cell type which expressed GM-CSF mRNA was not established. While $T$ cells were reported to be the main producer of GM-CSF in peripheral blood, ${ }^{15}$ monocytes and alveolar macrophages also have been shown to be capable of producing GMCSF. ${ }^{1617}$ It is conceivable that the nature of the exogenous stimulus, presumed to be present in the sarcoid lung, affects which cell type expresses GM-CSF as is the case in human peripheral blood mononuclear cells. ${ }^{16}$ In situ hybridisation experiments are currently under way to determine which cell expresses GM-CSF.

GM-CSF stimulates such activities of monocyte/macrophage lineage cells as proliferation, differentiation, antigen presentation, and production of effector molecules. ${ }^{1018}$ Although the effects of GM-CSF on human monocyte/macrophage lineage cells in the lung have not been fully examined, Nakata et al recently reported that GM-CSF stimulates the proliferation of human alveolar macrophages in vitro. ${ }^{19}$ On the other hand, several reports have shown that the alveolar macrophages in the sarcoid lung have undergone similar activation to those mentioned above-for example, proliferation, antigen presentation, and cytokine release. ${ }^{120-22}$ It would be interesting to see how GM-CSF is involved in such activation.

Molecular cloning and recombinant protein production of GM-CSF have facilitated studies of its properties. Its diverse in vitro effects on various types of cells have been elucidated, but little is known about what it actually does in pathological states in vivo. The results presented here could be a clue to the role of GM-CSF in pulmonary sarcoidosis. 
1 Hunninghake GW. Release of interleukin-1 by alveolar macrophages of patients with active pulmonary sarcoidosis. Am Rev Respir Dis 1984;129:569-72.

2 Pinkston P, Bitterman PB, Crystal RG. Spontaneous release of interleukin-2 by lung $T$ lymphocytes in active pulmonary sarcoidosis. $N$ Engl $f$ Med 1983;308: pulmonary

3 Robinson BWS, McLemore TL, Crystal RG. Gamma interferon is spontaneously released by alveolar macrophages and lung $\mathrm{T}$ lymphocytes in patients with pulmonary sarcoidosis. $f$ Clin Invest 1985;75:1488-95.

4 Itoh A, Yamaguchi E, Kuzumaki N, Okazaki N, Furuya $\mathrm{K}$, Abe S, et al. Expression of granulocyte-macrophage colony-stimulating factor mRNA by inflammatory cells in the sarcoid lung. Am $\mathcal{F}$ Respir Cell Mol Biol 1990; 3:245-9.

5 Hunninghake GW, Crystal RG. Pulmonary sarcoidosis. A disorder mediated by excess helper T-lymphocyte activity at sites of disease activity. $N$ Engl f Med 1981;305: 429-34.

6 Yamaguchi E, Okazaki N, Tsuneta Y, Abe S, Terai T, Kawakami $\mathrm{Y}$. Interleukins in pulmonary sarcoidosis. Dissociative correlations of lung interleukins 1 and 2 with the intensity of alveolitis. Am Rev Respir Dis 1988; 138: $645-51$.

7 Wong GG, Witek JS, Temple PA, Wilkens KM, Leary AC, Luxenberg DP, et al. Human GM-CSF: molecular cloning of the complementary DNA and purification of the natural and recombinant proteins. Science 1985;228:810-5.

8 Yamaguchi E, Okazaki N, Itoh A, Furuya K, Abe S, Kawakami Y. Enhanced expression of CD2 antigen on lung T cells. Am Rev Respir Dis 1991;143:829-33.

9 Cormier Y, Bélanger J, Laviolette M. Prognostic significance of bronchoalveolar lymphocytosis in farmer's lung. Am Rev Respir Dis 1987;135:692-5.

10 Kelso A, Metcalf D. T lymphocyte-derived colony-stimulating factors. Adv Immunol 1990;48:69-105.

11 Kreipe H, Radzun HJ, Heidorn K, Barth J, Kiemle-Kallee J, Petermann W, et al. Proliferation, macrophage colonystimulating factor, and macrophage colony-stimulating factor-receptor expression of alveolar macrophages in active sarcoidosis. Lab Invest 1990;62:697-703.

12 DeRemee RA, Rohrbach MS. Serum angiotensin- converting enzyme activity in evaluating the clinical course of sarcoidosis. Ann Intern Med 1980;92:361-5.

13 Keogh BA, Crystal RG. Alveolitis: the key to the interstitial lung disorders. Thorax 1982;37:1-10.

14 Costabel U, Bross KJ, Guzman J, Nilles A, Rühle KH, Matthys $\mathrm{H}$. Predictive value of bronchoalveolar $\mathrm{T}$ cell subsets for the course of pulmonary sarcoidosis. Ann subsets for the course of pulmor
NY Acad Sci 1986;465:418-26.

15 Oster W, Lindemann A, Mertelsmann R, Herrmann F. Production of macrophage-, granulocyte-, granulocytemacrophage- and multi- colony-stimulating factor by peripheral blood cells. Eur f Immunol 1989;19:543-7.

16 Lee M-T, Kaushansky K, Ralph P, Ladner MB. Differential expression of M-CSF, G-CSF, and GMCSF by human monocytes. I Leukocyte Biol 1990; 47:275-82.

17 Howell CJ, Pujol J-L, Crea AEG, Davidson R, Gearing $\mathrm{AJH}$, Godard $\mathrm{PH}$, et al. Identification of an alveolar macrophage-derived activity in bronchial asthma that enhances leukotriene $\mathrm{C}_{4}$ generation by human eosinophils stimulated by ionophore A23187 as a granulocyte-macrophage colony-stimulating factor. $\mathrm{Am} \mathrm{Rev}$ Respir Dis 1989;140:1340-7.

18 Ruef C, Coleman DL. Granulocyte-macrophage colonystimulating factor: pleiotropic cytokine with potential clinical usefulness. Rev Infect Dis 1990;12:41-62.

19 Nakata K, Akagawa KS, Fukayama M, Hayashi Y, Kadokura M, Tokunaga T. Granulocyte-macrophage colony-stimulating factor promotes the proliferation of human alveolar macrophages in vitro. $\mathcal{f}$ Immunol $\vec{N}$ 1991;147:1266-72.

20 Bitterman PB, Saltzman LE, Adelberg S, Ferrans VJ, Crystal RG. Alveolar macrophage replication. One mechanism for the expansion of the mononuclear 을 phagocyte population in the chronically inflamed lung. $\mathcal{f}$ Clin Invest 1984;74:460-9.

21 Lem VM, Lipscomb MF, Weissler JC, Nunez G, Ball EJ, Stastny $\mathrm{P}$, et al. Bronchoalveolar cells from sarcoid patients demonstrate enhanced antigen presentation. f Immunol 1985;135:1766-71.

22 Baughman RP, Strohofer SA, Buchsbaum J, Lower EE. Release of tumor necrosis factor by alveolar macrophages of patients with sarcoidosis. 7 Lab Clin Med 1990;115:36-42. 